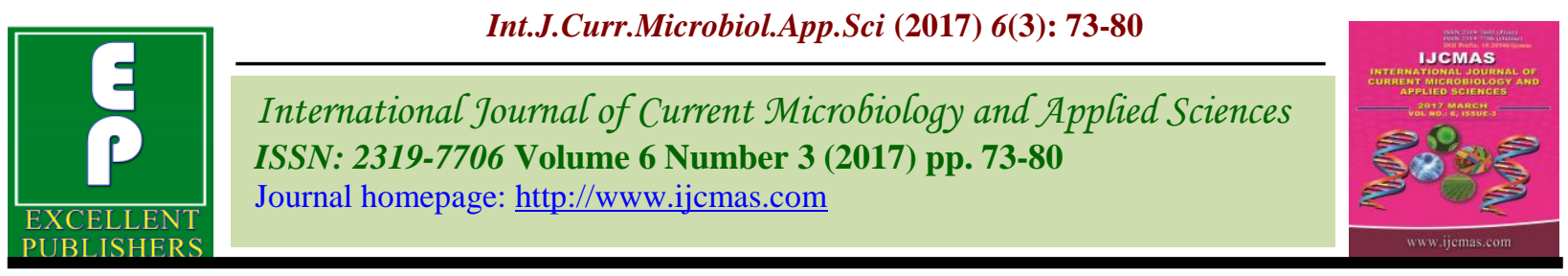

Original Research Article

https://doi.org/10.20546/ijcmas.2017.603.007

\title{
Performance of Different Basmati Rice on Phenology, Growth and Quality under Different Nitrogen Scheduling as Dry DSR Sown Condition in IGP
}

\author{
Mohinder Singh*, D.B. Yadav, Naveen Kumar, Suresh K. Kakraliya \\ and Rajbir Singh Khedwal
}

\author{
Department of Agronomy, CCS Haryana Agricultural University, Hisar-125004, India \\ *Corresponding author
}

\section{A B S T R A C T}

\begin{tabular}{|l|}
\hline K e y w o r d s \\
Basmati rice, \\
Cultivars, Direct \\
seeded rice, \\
Nitrogen, Nitrogen \\
scheduling.
\end{tabular}

To standardize the nitrogen scheduling in DSR, a field was conducted with different Basmati rice varieties with different nitrogen rates and splits at CCS Haryana Agricultural University, Regional Research Station at Karnal, India during rainy kharif seasons of 2014 and 2015. Nitrogen had significant positive effect on basmati rice crop resulting in improvement in plant height, number of tillers and effective tillers, grains/panicle, panicle length, 1000-grain weight, grain yield and straw yield with increase in dose from 90 to 100 and $110 \mathrm{~kg} \mathrm{ha}^{-1}$ in succession. Also, the grain yield was further improved with increase in number of splits from three to four. Nitrogen at $110 \mathrm{~kg} \mathrm{ha}^{-1}$ with four splits at $0,20,40$, and 60 days after sowing was realized to be the optimum schedule for attaining maximum grain yield (49.3 \& $50.2 \mathrm{q} \mathrm{ha}^{-1}$ ) and yield attributes. Among basmati varieties, highest grain yield (47.5 \& $48.9 \mathrm{q} \mathrm{ha}^{-1}$ ) was recorded in HB-2 followed by PB-1121 (47.1 \& $47.0 \mathrm{q}$ $\mathrm{ha}^{-1}$ ), PB-1 (43.9 \& $44.6 \mathrm{q} \mathrm{ha}^{-1}$ ) and PB-1509 (42.9 \& $43.8 \mathrm{q} \mathrm{ha}^{-1}$ ) under direct seeding conditions.

\section{Introduction}

Rice (Oryza sativa L.) is one of the most important cereal crops of the world, grown in wide range of climatic zones. Rice is the staple food for nearly half of the world's population. The crop occupies one-third of the world's total area planted to cereals and provides 35 to $60 \%$ of the calories consumed by 2.7 billion people. Direct seeded rice (DSR) is becoming popular as alternative to conventional transplanting under continuous flooding in Asia (Farooq et al., 2011). Nitrogen use efficiency (NUE) of rice is usually low due to volatilization, runoff, denitrification and leaching losses. Moreover, direct seeded rice soils are often exposed to dry and wet conditions and difference in $\mathrm{N}$ dynamics and losses pathways often results in different fertilizer recoveries in aerobic soils (De Datta and Buresh, 1989). Rice cultivars usually exhibit vigorous vegetative growth under direct seeded condition and perform poorly during reproductive stages due to $\mathrm{N}$ deficiency. However, high plant density and absence of transplanting shock in direct seeded rice produces high leaf area and tillers under favorable growing conditions. Nitrogen application has great impact on crop yield in rice when acquired during early and mid 
tillering stages to produce high number of panicles, spikelets per panicle (Murty et al., 1992). Thus, for maximum yield and increased NUE, optimum nitrogen schemes require to be developed for this rice system (Mahajan et al., 2011). High fertilizer $\mathrm{N}$ efficiency in rice can be achieved through $\mathrm{N}$ efficient varieties; improved timing, application methods and better incorporation of basal fertilizer without standing water (De Datta, 1986; Ali et al., 2007). Split application is one of strategies for efficient use of $\mathrm{N}$ fertilizers throughout the growing season by synchronizing with plant demand, reducing denitrification losses and improved $\mathrm{N}$ uptake for maximum straw and grain yield, and harvest index in DSR (Fageria, 2010, Lampayan et al., 2010). However, further studies to evaluate crop dry matter and $\mathrm{N}$ translocation response to nutrient supply to find optimum $\mathrm{N}$ management strategies for improved productivity and NUE in DSR were suggested (Mahajan and Timsina, 2011). This suggest optimizing split doses to different crop growth stages for high yield in DSR and find appropriate management of nitrogenous fertilizers to improve NUE.

\section{Materials and Methods}

A field experiment was conducted at CCS Haryana Agricultural University, Regional Research Station, Karnal during kharif 2014 and 2015. The soil of the experimental field was clay loam in texture, slightly alkaline in reaction, low in available nitrogen, and medium in phosphorus and potassium. The treatments included four varieties of basmati rice, viz. PB-1121, PB-1509, PB-1 and HB-2 and six N levels, viz. N @ 90, 100, $110 \mathrm{~kg} / \mathrm{ha}$ applied as 3-splits (at 0, 15, 50 days after sowing (DAS) or 4-splits (0, 20, 40, 60 DAS). The experiment was laid out in split-plot design with cultivars in main plots and nitrogen levels in sub-plots with three replications. Full dose of phosphorus $(30 \mathrm{~kg}$ $\mathrm{ha}^{-1}$ ) and zinc sulphate (25 $\left.\mathrm{kg} \mathrm{ha}^{-1}\right)$ were applied at the time of sowing. $11.5 \mathrm{k} \mathrm{N}$ available from di-ammonium phosphate (used as source of $\mathrm{P}$ ) was taken as basal dose and the remaining $\mathrm{N}$ was applied in equal splits. Recommendations of the state University were adopted for raising the crop. Twenty $\mathrm{kg}$ seed per hectare was used for sowing. The seeds were soaked in water along with carbendazim $(1 \mathrm{~g} / \mathrm{L}$ water solution per $\mathrm{kg}$ seed) for 24 hours and then water was completely drained. The soaked seeds were sown in the evening by using seed drill on 10 June, 2014 and 24 June 2015, keeping row spacing of $20 \mathrm{~cm}$ and depth of $2-3 \mathrm{~cm}$. Preemergence herbicide pendimethalin $1.0 \mathrm{~kg} / \mathrm{ha}$ was applied just after sowing (JAS) in a spray volume of $500 \mathrm{~L}$ water and bispyribac sodium $25 \mathrm{~g} \mathrm{ha}^{-1}$ at 20 DAS as spray in a spray volume of $300 \mathrm{~L}$ water. Manual weeding was also done at 40 DAS to avoid any infestation of weeds in the crop. Data on yield attributes and yield were recorded at harvest of the crop. Harvesting was done on 1 November 2014 and 14 November 2015.

\section{Results and Discussion}

\section{Days to $50 \%$ flowering}

Days to $50 \%$ flowering (Table 1) showed that tall cultivars (HB-2, PB-1121 and PB-1) took longer time to reach $50 \%$ flowering as compared to semi dwarf cultivar (PB-1509). During both the years, basmati cultivar HB-2 took maximum (97 and 100 days) days to 50 $\%$ flowering which were statistically at par with PB-1121 (97 and 99 days) but significantly more than PB-1 (89 and 92 days) and PB-1509 (85 and 86 days). Days to 50\% flowering increased with increasing $\mathrm{N}$ levels and number of splits. Maximum days to $50 \%$ flowering were recorded at $110 \mathrm{~kg} \mathrm{~N}^{-1}$ with four splits $(0,20,40$ and 60 DAS) which was significantly higher than rest of the treatments and minimum number of days to $50 \%$ 
flowering were recorded at $90 \mathrm{~kg} \mathrm{~N}$ ha ${ }^{-1}$ with three splits (0, 15 and 50 DAS) during years of succession. Number of days to $50 \%$ flowering in basmati cultivars increased with increase in $\mathrm{N}$ doses from 90 (87-91 days) to 100 (90-95 days) and $110 \mathrm{~kg} \mathrm{ha}^{-1}$ (94-100 days) in succession. Similarly, there was delay in $50 \%$ flowering with increase in number of splits from three (87-97 days) to four (88-100 days) at same level of nitrogen. Increasing levels of $\mathrm{N}$ helped the plants to remain photosynthetically active for longer time and thus prolonged vegetative period. Similar results have been reported earlier as well (Chopra et al., 2006; Anonymous, 2004).

\section{Days to maturity}

The data indicated in (Table 1) showed that tall basmati cultivars HB-2, PB-1121 and PB1 matured late, whereas the semi dwarf cultivar PB-1509 matured earlier in both the years of study. Increasing levels of $\mathrm{N}$ and number of splits of application delayed maturity of all the basmati cultivars. Maximum days to maturity (131 and 135 days) were recorded at $110 \mathrm{~kg} \mathrm{~N}^{-1}$ with four splits and found significantly higher than $90 \mathrm{~kg} \mathrm{~N} \mathrm{ha}^{-1}$ with 3 split application (121 and 124 days). There was increase days to maturity with increase in $\mathrm{N}$ doses from 90 (121-126 days) to 100 (124-130 days) and $110 \mathrm{~kg} \mathrm{~N} \mathrm{ha}^{-1}$ (128-135 days) in succession. Similarly, days to maturity increased with increase in number of splits from three (121125 days) to four (123-135 days) at the same level of nitrogen. Higher level of nitrogen increased number of splits increased the cell division and cell enlargement, which slowed the development of phenophases and finally the process of senescence, hence delayed in maturity (Ashrafuzzaman et al., 2009).

\section{Plant height}

Plant height of basmati rice was influenced by cultivars and nitrogen levels with number of splits are presented in table 2. The plant height of basmati cultivars increased successively with the advancement in the age of crop, highest recorded at maturity. Among varieties, HB-2 attained maximum plant height at $60(69.1$ and $69.7 \mathrm{~cm}), 80(89.8$ and $88.6 \mathrm{~cm})$ DAS and at maturity (105.2 and $105.9 \mathrm{~cm}$ ), which was statistically at par with PB-1121 but significantly higher than PB-1 and PB-1509 during both the years. At 40 DAS basmati cultivar HB 2 recorded more height than PB 1121, PB 1 and HB 2. Varietal differences in growth parameters of various basmati rice cultivars were also recorded by Mannan et al., (2010).

Increase in $\mathrm{N}$ levels from 90 to $110 \mathrm{~kg} \mathrm{ha}^{-1}$ increased plant height at all crop growth stages (Table 2). Increasing the number of splits also increased the plant height at all crop growth stages except at 40 DAS where application of $\mathrm{N}$ in three splits resulted in higher plant height as compared to four splits at same levels of nitrogen. Maximum plant height was recorded at maturity (104.3 and $102.1 \mathrm{~cm})$ at $110 \mathrm{~kg} \mathrm{~N} \mathrm{ha}^{-1}$ with four splits, which was significantly higher than the rest of treatments in both the years.

Evidently, minimum plant height at maturity (88.9 and $92.5 \mathrm{~cm}$ ) was recorded at $90 \mathrm{~kg} \mathrm{~N}$ $\mathrm{ha}^{-1}$ with three splits. There was increase in plant height with increase in $\mathrm{N}$ doses from 90 $(88.9-93.9 \mathrm{~cm})$ to $100(95.7-98.6 \mathrm{~cm})$ and 110 $\mathrm{kg} \mathrm{ha}{ }^{-1}(98.6-104.3 \mathrm{~cm})$ in succession at maturity. Similarly, plant height increased with increase in number of splits from three $(88.9-99.1 \mathrm{~cm})$ to four $(93.1-104.3 \mathrm{~cm})$ at same level of nitrogen. Increase in plant height with increase in number of splits has been reported by Ehsanullah et al., (2012) and Awan et al., (2011). There was close impact elaborated by regression lines drawn between grain yield and plant height as (Fig. 2) with following equations, Grain yield $=0.439$ plant height $+2.98\left(r^{2}=0.86\right)$. 
Number of tillers m.r.l. ${ }^{-1}$

The cultivars differed with respect to number of tillers m.r.l. ${ }^{-1}$ at all the growth stages. The data presented in table 3 showed that there was no significant difference in number of tillers m.r.l. ${ }^{-1}$ among cultivars at 40 DAS number of tillers but increased with the advancement in crop age up to 80 DAS. The HB-2 produced maximum number of tillers m.r.l. ${ }^{-1}$ which was statistically alike with PB1121 cultivar and significantly better than PB1 and PB-1509 at 60 and 80 DAS. Maximum number of tillers m.r.l. ${ }^{-1}$ (87.5 and 88.2) was recorded in HB-2 while minimum was recorded with cultivar PB-1509 (80.5 and $81.3)$ at 80 DAS. Varietal differences in growth parameters of various basmati rice cultivars were also recorded by Paliwal et al., (1996).

Nitrogen application rates and number of splits significantly influenced the number of tillers m.r.l. ${ }^{-1}$ at different crop growth stages.
Data in the table 3 indicated that the maximum number of tillers m.r.l. ${ }^{-1}$ was recorded under $110 \mathrm{~kg} \mathrm{~N}^{-1}$ with four splits $(0,20,40$ and 60 DAS) which was statistically alike at $110 \mathrm{~kg} \mathrm{~N}^{-1}$ with three splits $(0,15$ and 50 DAS) but significantly higher than rest of treatments. Data in the table 3 also indicated at 40 DAS that number of tillers were higher in three split than the four splits might be due to higher amount of $\mathrm{N}$ is applied at same level of dose. There was increase in tillers m.r.l. ${ }^{-1}$ with increase in $\mathrm{N}$ doses from 90 (77.2-81.3) to 100 (83.3- 87.0) and $110 \mathrm{~kg} \mathrm{ha}^{-1}(88.7-92.0)$ in succession at 80 DAS. Similarly, tillers m.r.l. ${ }^{-1}$ increased with number of splits from three (77.2-89.1) to four (80.0-95.5) at same level of nitrogen in years of succession. Similar trends have been reported by Kaushal et al., (2010). There facts were further elaborated by regression lines drawn between grain yield and effective tillers with following equation, Grain yield = 0.527 number of effective tillers +6.582 $\left(r^{2}=0.85\right)$.

Table.1 Effect of nitrogen levels and time of application on phenophases of different cultivar of basmati rice

\begin{tabular}{|c|c|c|c|c|}
\hline \multirow{2}{*}{$\begin{array}{l}\text { Treatment } \\
\text { Cultivars }\end{array}$} & \multicolumn{2}{|c|}{ Days to $50 \%$ flowering } & \multicolumn{2}{|c|}{ Days to maturity } \\
\hline & 2014 & 2015 & 2014 & 2015 \\
\hline PB-1121 & 97 & 99 & 128 & 133 \\
\hline PB-1509 & 85 & 86 & 113 & 116 \\
\hline PB-1 & 89 & 92 & 128 & 132 \\
\hline HB-2 & 97 & 100 & 132 & 135 \\
\hline $\mathrm{SEm} \pm$ & 0.7 & 0.6 & 1.2 & 1.2 \\
\hline $\mathrm{CD}$ at $5 \%$ & 2 & 2 & 4 & 4 \\
\hline \multicolumn{5}{|c|}{ Nitrogen levels $\left(\mathrm{kg} \mathrm{ha}^{-1}\right)$ and number of splits } \\
\hline 90-3 splits & 87 & 89 & 121 & 124 \\
\hline 90-4 splits & 89 & 91 & 123 & 126 \\
\hline 100-3 splits & 90 & 93 & 124 & 128 \\
\hline $100-4$ splits & 93 & 95 & 127 & 130 \\
\hline 110-3 splits & 94 & 97 & 128 & 132 \\
\hline $110-4$ splits & 97 & 100 & 131 & 135 \\
\hline SEm \pm & 0.4 & 0.4 & 0.4 & 0.4 \\
\hline CD at $5 \%$ & 1 & 1 & 1 & 1 \\
\hline
\end{tabular}


Table.2 Effect of nitrogen levels and time of application on plant height of different cultivars of basmati rice at different growth stages

\begin{tabular}{|l|c|c|c|c|c|c|c|c|}
\hline \multirow{3}{*}{ Treatment } & \multicolumn{9}{|c|}{ Plant height (cm) } \\
\cline { 2 - 9 } Cultivars & $\mathbf{4 0}$ DAS & \multicolumn{2}{|c|}{ 60DAS } & \multicolumn{2}{c|}{ 80 DAS } & \multicolumn{2}{c|}{ At maturity } \\
\cline { 2 - 9 } & $\mathbf{2 0 1 4}$ & $\mathbf{2 0 1 5}$ & $\mathbf{2 0 1 4}$ & $\mathbf{2 0 1 5}$ & $\mathbf{2 0 1 4}$ & $\mathbf{2 0 1 5}$ & $\mathbf{2 0 1 4}$ & $\mathbf{2 0 1 5}$ \\
\hline PB-1121 & 39.6 & 40.1 & 68.8 & 69.7 & 86.9 & 87.7 & 104.1 & 102.9 \\
\hline PB-1509 & 35.3 & 36.4 & 62.0 & 62.2 & 79.5 & 79.3 & 89.2 & 90.8 \\
\hline PB-1 & 39.3 & 41.3 & 63.1 & 63.7 & 80.7 & 80.6 & 93.3 & 93.1 \\
\hline HB-2 & 37.9 & 40.4 & 69.1 & 69.7 & 89.8 & 88.6 & 105.2 & 105.9 \\
\hline SEm \pm & 0.4 & 0.8 & 1.3 & 1.4 & 1.7 & 1.6 & 2.5 & 0.9 \\
\hline CD at 5\% & 1.4 & 2.7 & 4.5 & 2.7 & 5.8 & 5.8 & 8.8 & 3.2 \\
\hline Nitrogen levels & $\left(\mathbf{k g ~ h a}^{-1}\right.$ ) and number of splits & \multicolumn{3}{|c|}{} \\
\hline 90-3 splits & 37.9 & 37.8 & 61.5 & 62.7 & 80.3 & 80.3 & 88.9 & 92.5 \\
\hline 90-4 splits & 36.8 & 37.2 & 62.9 & 64.0 & 82.0 & 81.1 & 93.1 & 93.9 \\
\hline 100-3 splits & 39.6 & 39.9 & 64.7 & 65.9 & 83.5 & 83.6 & 95.7 & 96.5 \\
\hline 100-4 splits & 38.8 & 39.2 & 66.6 & 67.4 & 85.6 & 85.2 & 98.6 & 98.1 \\
\hline 110-3 splits & 41.7 & 42.4 & 68.9 & 69.1 & 86.0 & 85.7 & 98.6 & 99.1 \\
\hline $110-4$ splits & 40.7 & 40.8 & 70.3 & 71.5 & 88.1 & 88.4 & 104.3 & 102.1 \\
\hline SEm \pm & 0.2 & 0.2 & 0.7 & 0.8 & 0.8 & 0.9 & 1.0 & 0.9 \\
\hline CD at 5\% & 0.5 & 0.5 & 2.0 & 2.2 & 2.3 & 2.7 & 2.2 & 2.6 \\
\hline
\end{tabular}

Table.3 Effect of nitrogen levels and time of application on number of tillers of different cultivars of basmati rice at different growth stages

\begin{tabular}{|l|c|c|c|c|c|c|}
\hline \multirow{2}{*}{$\begin{array}{l}\text { Treatment } \\
\text { Cultivars }\end{array}$} & \multicolumn{6}{|c|}{ Number of tillers m.r.l. } \\
\cline { 2 - 7 } & \multicolumn{2}{|c|}{ 40 DAS } & \multicolumn{2}{c|}{ 60DAS } & \multicolumn{2}{c|}{ 80 DAS } \\
\cline { 2 - 7 } & $\mathbf{2 0 1 4}$ & $\mathbf{2 0 1 5}$ & $\mathbf{2 0 1 4}$ & $\mathbf{2 0 1 5}$ & $\mathbf{2 0 1 4}$ & $\mathbf{2 0 1 5}$ \\
\hline PB-1121 & 40.7 & 41.4 & 69.0 & 71.1 & 86.0 & 87.3 \\
\hline PB-1509 & 39.5 & 40.7 & 65.6 & 65.6 & 80.5 & 81.3 \\
\hline PB-1 & 40.6 & 41 & 66.3 & 66.7 & 83.4 & 83.8 \\
\hline HB-2 & 40.7 & 42.4 & 71.4 & 72.1 & 87.5 & 88.2 \\
\hline SEm \pm & 2.9 & 4.6 & 0.8 & 0.4 & 0.9 & 1.4 \\
\hline CD at 5\% & NS & NS & 2.8 & 1.3 & 3.0 & 1.7 \\
\hline Nitrogen levels (kg ha-1) and number of splits & & & & \\
\hline $90-3$ splits & 37.0 & 38.7 & 62.8 & 64.7 & 77.2 & 78.5 \\
\hline $90-4$ splits & 35.7 & 36.3 & 64.0 & 66.2 & 80.0 & 81.3 \\
\hline $100-3$ splits & 41.0 & 42.1 & 67.5 & 68.0 & 82.4 & 83.3 \\
\hline $100-4$ splits & 40.3 & 40.2 & 69.9 & 70.1 & 88.5 & 87.0 \\
\hline $110-3$ splits & 44.7 & 46.8 & 71.3 & 70.8 & 89.1 & 88.7 \\
\hline $110-4$ splits & 43.5 & 44.2 & 72 & 73.7 & 92.0 & 91.5 \\
\hline SEm \pm & 2.0 & 1.5 & 1.1 & 1.0 & 1.2 & 0.9 \\
\hline CD at 5\% & 5.8 & 4.3 & 3.0 & 3.1 & 3.4 & 2.6 \\
\hline
\end{tabular}


Table.4 Effect of nitrogen levels and time of application on grain yield and biological yield of different cultivars of basmati rice

\begin{tabular}{|c|c|c|c|c|c|}
\hline \multirow{2}{*}{$\begin{array}{l}\text { Treatment } \\
\text { Cultivars }\end{array}$} & \multicolumn{2}{|c|}{$\begin{array}{c}\text { Grain yield } \\
\left(\mathbf{q} \mathbf{h a}^{-1}\right)\end{array}$} & \multirow{2}{*}{$\begin{array}{c}\text { Pooled Grain } \\
\text { yield } \\
\left(\mathbf{q ~ h a}^{-1}\right) \\
\end{array}$} & \multicolumn{2}{|c|}{$\begin{array}{c}\text { Biological } \\
\text { yield }\left(q \text { ha }^{-1}\right)\end{array}$} \\
\hline & 2014 & 2015 & & 2014 & 2015 \\
\hline PB-1121 & 47.1 & 47.1 & 47.1 & 109.7 & 106.8 \\
\hline PB-1509 & 42.9 & 43.4 & 43.4 & 94.6 & 96.7 \\
\hline PB-1 & 43.9 & 44.2 & 44.2 & 98.2 & 99.9 \\
\hline HB-2 & 47.5 & 48.2 & 48.2 & 106.9 & 111.5 \\
\hline SEm \pm & 0.9 & 1.0 & 1.0 & 1.8 & 2.4 \\
\hline $\mathrm{CD}$ at $5 \%$ & 3.1 & 3.3 & 3.3 & 6.3 & 8.2 \\
\hline \multicolumn{6}{|c|}{ Nitrogen levels $\left(\mathrm{kg} \mathrm{ha}^{-1}\right)$ and number of splits } \\
\hline 90-3 splits & 41.9 & 42.6 & 42.2 & 91.2 & 91.5 \\
\hline 90-4 splits & 42.9 & 43.9 & 43.5 & 95.0 & 95.8 \\
\hline 100-3 splits & 44.4 & 45.0 & 44.8 & 99.0 & 99.5 \\
\hline 100-4 splits & 45.8 & 46.5 & 46.2 & 104.0 & 105.7 \\
\hline $110-3$ splits & 47.6 & 48.5 & 48.1 & 109.2 & 111.9 \\
\hline 110-4 splits & 49.3 & 50.2 & 49.8 & 115.6 & 117.9 \\
\hline SEm \pm & 0.5 & 0.6 & 0.5 & 1.2 & 1.1 \\
\hline $\mathrm{CD}$ at $5 \%$ & 1.3 & 1.6 & 1.4 & 3.4 & 3.1 \\
\hline
\end{tabular}

Fig.1 Regression lines showing relation between grain yield $\left(\mathrm{q} \mathrm{ha}^{-1}\right)$ with biological yield $\left(\mathrm{q} \mathrm{ha}^{-1}\right)$

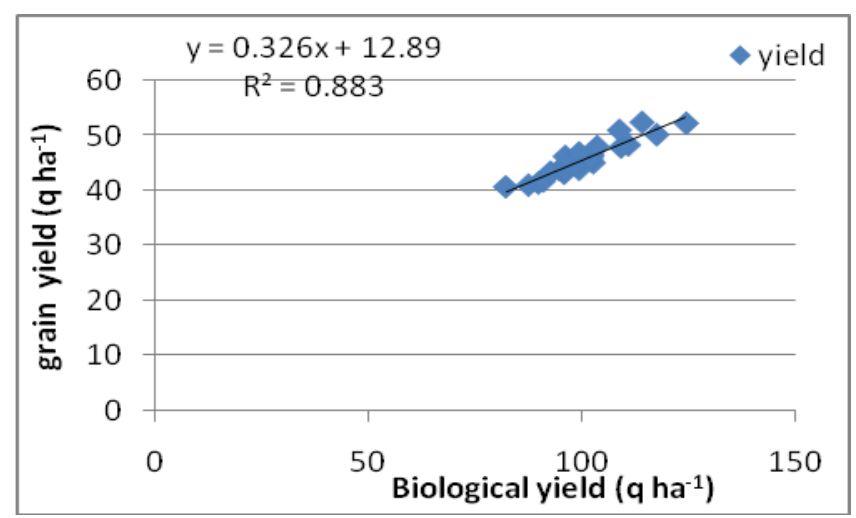

\section{Grain yield}

The data pertaining to grain yield presented in table 4 indicate that the grain yield of different cultivars of basmati rice differed significantly. Long duration cultivars (HB-2, PB-1121 and PB-1) performed better than short duration cultivar (PB-1509) in respect of grain yield. Basmati cultivar HB-2 gave the
Fig.2 Regression lines showing relation between grain yield $\left(\mathrm{q} \mathrm{ha}^{-1}\right)$ with plant height at maturity $(\mathrm{cm})$

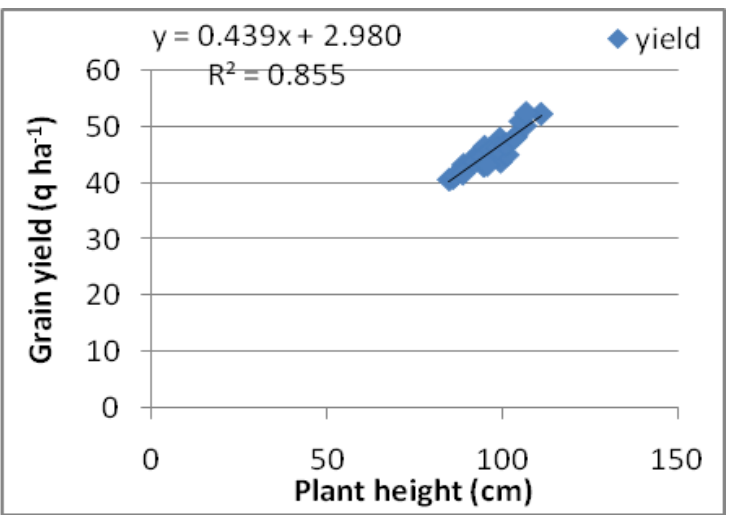

highest grain yield (47.5 and $48.2 \mathrm{q} \mathrm{ha}^{-1}$ ) which was statistically alike to with PB1121(47.1 and 47.1 q ha $\left.{ }^{-1}\right)$ but significantly higher than PB-1 (43.9 and $44.2 \mathrm{q} \mathrm{ha}^{-1}$ ) and PB-1509 (42.9 and $43.4 \mathrm{q} \mathrm{ha}^{-1}$ ). Minimum yield was recorded with cultivars PB 1509. Singh et al., (1999) also observed higher grain yield of Pusa Basmati-1 than Taraori Basmati. 
Grain yield of cultivars increased significantly with increase in $\mathrm{N}$ dose and number of splits. Maximum grain yield was recorded with 110 $\mathrm{kg} \mathrm{N} \mathrm{ha}{ }^{-1}$ with four number of splits at 0,20 , 40, and 60 DAS (49.3 and $50.2 \mathrm{q} \mathrm{ha}^{-1}$ ) which was significantly higher than rest of treatments (Table 4). Minimum grain yield was recorded with $90 \mathrm{~kg} \mathrm{~N}^{-1}$ with three splits at 0,15 and 50 DAS (41.9 and $42.6 \mathrm{q}$ $\left.\mathrm{ha}^{-1}\right)$. There was increase in grain yield of basmati rice with increase in $\mathrm{N}$ doses from 90 (41.9-43.9 $\left.\mathrm{q} \mathrm{ha}^{-1}\right)$ to $100\left(44.4-46.5 \mathrm{q} \mathrm{ha}^{-1}\right)$ and $110 \mathrm{~kg} \mathrm{ha}{ }^{-1}\left(47.6-50.2 \mathrm{q} \mathrm{ha}^{-1}\right)$ in succession. Similarly, grain yield increased with increase in number of splits from three (41.9-47.6 $\mathrm{q} \mathrm{ha}^{-1}$ ) to four (42.9-50.2 q ha-1). Similar results were also reported earlier by Pramanik and Bera (2013) and Abou-Khalifa (2012). Pooled grain yield of basmati cultivars significantly increased with increase in $\mathrm{N}$ dose and number of splits (Table 4). Maximum grain yield was recorded with 110 $\mathrm{kg} \mathrm{N} /$ ha with four number of splits at 0,20 , 40 and 60 DAS (49.8 q/ha) which was significantly higher than rest of the treatments. There was increase in grain yield of basmati rice with increase in $\mathrm{N}$ doses from $90(42.2-43.5)$ to $100(44.8-46.2)$ and 110 $\mathrm{kg} / \mathrm{ha} \quad(48.1-49.8 \mathrm{q} / \mathrm{ha})$ in succession. Similarly, grain yield increased with increase in number of splits from three (42.2-48.1 $\mathrm{q} / \mathrm{ha}$ ) to four (43.5-49.8 q/ha) at same level of nitrogen. Similar findings have also been reported by Yadav and Yadav (2012). Increase in grain yield at higher nitrogen rates might be primarily due to increase in chlorophyll concentration in leaves leading to higher photosynthetic rate.

\section{Biological yield}

The data presented in table 4 indicate that biological yield of different basmati cultivars differed significantly. Maximum biomass production was observed with basmati cultivar HB-2 (106.9 and $111.5 \mathrm{q} \mathrm{ha}^{-1}$ ) which was statistically at par with PB-1121(109.7 and $106.9 \mathrm{q} \mathrm{ha}^{-1}$ ) but significantly higher than PB-1 (98.2 and $99.9 \mathrm{q} \mathrm{ha}^{-1}$ ) and PB-1509 (94.6 and $96.7 \mathrm{q} \mathrm{ha}^{-1}$ ). Minimum biological yield was recorded with PB-1509 during 2014 and 2015. Biological yield of basmati cultivars increased with increase in $\mathrm{N}$ dose and number of splits. The maximum biological yield (115.6 and $117.6 \mathrm{q} \mathrm{ha}^{-1}$ ) was recorded with $110 \mathrm{~kg} \mathrm{~N}^{-1}$ with four splits $(0,20,40$ and 60 DAS) which was significantly higher than rest of treatments. Minimum biological yield (91.2 and $91.5 \mathrm{q}$ $\mathrm{ha}^{-1}$ ) was recorded at $90 \mathrm{~kg} \mathrm{~N}^{-1}$ with three splits $(0,15$ and 50 DAS). There was increase in biological yield of basmati rice with increase in $\mathrm{N}$ doses from 90 (91.2-95.8 $\left.\mathrm{q} \mathrm{ha}^{-1}\right)$ to $100\left(99.0-105.7 \mathrm{q} \mathrm{ha}^{-1}\right)$ and $110 \mathrm{~kg} \mathrm{ha}^{-1}$ (109.2-117.9 q ha $\left.{ }^{-1}\right)$ in succession. Similarly, biological yield increased with increase in number of splits from three (91.2-111.9 $\mathrm{q} \mathrm{ha}^{-}$ ${ }^{1}$ ) to four (95.0-117.9 $\mathrm{q} \mathrm{ha}^{-1}$ ) at same level of nitrogen. Sharma et al., (2012) also observed differences in growth, yield components and yield of different basmati rice cultivars with increase in nitrogen doses. There was close impact elaborated by regression lines drawn between grain yield and biological yield as (Fig. 1) with following equations, Grain yield $=0.326$ biological yield $+12.89\left(r^{2}=0.883\right)$.

\section{References}

Abou-Khalifa, A.A.B. 2012. Evaluation of some rice varieties under different nitrogen levels. Adv. App. Sci. Res., 3: 1144-1149.

Anonymous. 2004. Annual Report 2003-2004. Bangladesh Institute of Nuclear Agriculture, Mymensingh, Bangladesh.

Ashrafuzzaman, M., Islam, M.R., Ismail, Shahidullah, M.R. and Hanafi, M.M. 2009. Evaluation of six aromatic rice varieties for yield and yield contributing characters. Int. J. Agric. Bio., 11: 616-620.

Ali, M.A., Ladha, J.K.., Rickman, J. and Lales, J.S. 2007. Nitrogen dynamics in lowlandrice as affected by crop establishment and nitrogen management. $J$. Crop Improv., 20: 89-105. 
Awan, T.H., Ali, R., Manzoor, Z., Ahmed, M. and Akhtar, M. 2011. Effect of different nitrogen levels and row spacing on the performance of newly evolved medium grain rice variety KSK-133. J. Anim. Plant Sci., 21: 231-234.

Chopra, N.K., Chopra, N., Yadav, R.N. and Nagar, K.C. 2006. Effect of transplanting dates on seed yield and quality of paddy cv. Pusa-44. Seed Res. 34(2):218-220.

De Datta, S.K. 1986. Improving nitrogen fertilizer efficiency in lowland rice tropical Asia. Fert. Res., 9: 171-186.

De Datta, S.K. and Buresh, R.J. 1989. Integrated nitrogen management in irrigated rice. $A d v$. Agron., 10: 143-169.

Ehsanullah, J.K., Asghar, G., Hussain, M. and Rafiq, M. 2012. Effect of nitrogen fertilization and seedling density on fine rice yield in Faisalabad, Pakistan. Soil Environ., 31: 152-156.

Fageria, N.K. 2010. Optimal nitrogen fertilization timing for upland rice. In: $19^{\text {th }}$ World Congress of Soil Science, Soil Solution for a Changing World, Brisbane, Australia, pp: 176-179. 1-6 Aug. 2010.

Farooq, M., Siddique, K.H.M., Rehman, H., Aziz, T., Wahid, A. and Lee, D. 2011. Rice direct seeding experiences and challenges. Soil Till. Res., 111: 87-98.

Kaushal, A.K, Rana N.S, Singh A., Neeray S. and Strivastav A. 2010. Response of levels and split application of nitrogen is gerrn manured wetland rice (Oryza sativa L.. Asian J. Agric. Sci., 2(2): 42-46.

Lampayan, R.M., B.A.M. Bouman, J.L. de Dios, A.J. Espiritu, J.B. Soriano, A.T. Lactaoen, J.E. Faronilo and K.M. Thant, 2010. Yield of aerobic rice in rainfed lowlands of the Philippines as affected by nitrogen management and row spacing. Field Crops Res., 116: 165-174.

Mannan, M.A., Bhuiya, M.S.U., Hossain, H.M.A. and Akhand, M.I.M. 2010. Optimization of nitrogen rate for aromatic rice (Oryza sativa L.. Bangladesh J. Agric. Res., 35(1): 157165.

Murty, K.S., Dey, S.K. and Jachuk, P.J. 1992. Physiological traits of certain restorers in hybrid rice breeding. Int. Rice Res. 17: 7.

Mahajan, G., B.S. Chauhan and M.S. Gill. 2011. Optimal nitrogen fertilization timing and rate in dry-seeded rice in northwest India. Agron. J., 103: 1676-1682.

Paliwal, A.K., Kandalkar, V.S., Paraye, P.M. and Tomer, N.S. 1996. Effect of transplanting time on grain yield and its attributes in dwarf, scented rice (Oryza sativa) varieties. Indian J. Agric. Sci., 66(1): 48-50.

Pramanik, K. and Bera, A.K. 2013. Effect of seedling age and nitrogen fertilizer on growth, chlorophyll content, yield and economics of hybrid rice (Oryza sativa L. Int. J. Agron. Plant Prod., 4: 3489-3499.

Sharma, D., Sagwal, P.K., Singh, I. and Sangwan, A. 2012. Influence of different nitrogen and phosphorus levels on profitability, plant nutrient content, yield and quality in basmati cultivars. Int. J. I.T. Engin. App. Sci. Res., 1: 1-4.

Yadav, D.B. and Yadav, A. 2012. Dose standardization and scheduling of nitrogen application in direct seeded basmati rice. In: Proc. Extended Summaries of 3rd Int. Agron. Congress, New Delhi, India. November 26-30, 2012. 3: 720-721.

\section{How to cite this article:}

Mohinder Singh, D.B. Yadav, Naveen Kumar, Suresh K. Kakraliya and Rajbir Singh Khedwal. 2017. Performance of Different Basmati Rice on Phenology, Growth and Quality under Different Nitrogen Scheduling As Dry DSR Sown Condition in IGP. Int.J.Curr.Microbiol.App.Sci. 6(3): 73-80. doi: https://doi.org/10.20546/ijcmas.2017.603.007 